\title{
JUURNAL.RU
}

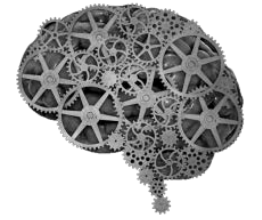

COMPANY GROUP "INTELLEKT"

Коровина Е.В., Марцева Т.Ю., Мулюкова В.В., Исаева М.А., Гусева И.Т. ФГБОУ ВПО Ульяновский государственный технический университет

Ульяновск, Россия

doi: 10.18411/lj2016-6-4-03

\section{Физико-химические аспекты миграции тяжелых металлов и нефтепродуктов в системе вода - донные отложения}

К одним из основных загрязняющих веществ, поступающие в природные водные системы, относятся тяжелые металлы (ТМ) и нефтепродукты (НП). Водоемы служат коллекторами всех видов загрязнения, где донные отложения служат депонирующей средой, аккумулирующие загрязняющие вещества. При изменении физико-химических условий в водоеме, а также при снижении интенсивности антропогенной нагрузки, загрязняющие вещества могут снова поступать из донных отложений в водную толщу и значительно влиять на водные ресурсы [1-4].

Цель настоящей работы - исследование влияния физико-химических факторов (pH, Eh), карбонатной жесткости на процессы миграции тяжелых металлов (Fe, $\mathrm{Zn}, \mathrm{Cu}, \mathrm{Ni}, \mathrm{Cd}, \mathrm{Pb})$ и нефтепродуктов в системе вода - донные отложения.

Объектами исследования являлись поверхностные воды и донные отложения Куйбышевского водохранилища на территории Ульяновской области. Сезонный отбор проб воды и донных отложений производился в период 2009-2014 гг. Исследования проводились на базе аккредитованной научно-исследовательской лаборатории физико-химического анализа ФГБОУ ВПО «Ульяновский государственный технический университет». 
Влияние $\mathrm{pH}$ среды и окислительно-восстановительных условий (Eh) на миграцию элементов в водной среде и выражается в том, что данные факторы контролируют осаждение ТМ из растворов, коагуляцию коллоидов, подвижность металлов. В сезонной динамике при увеличении $\mathrm{pH}$ воды от 7,35 (весна) до 8,15 (осень) растворенные катионные формы металлов могут переходить в нерастворенные формы, адсорбироваться на поверхности твердых частиц взвешенных веществ, находящихся в воде, и осаждаться в донные отложения. Исследования показали достоверную статистически значимую корреляционную зависимость (r>0,8), что при повышении $\mathrm{pH}$ водной среды (до 8,15) в осенний период возрастает миграция и накопление всех исследуемых тяжелых металлов из воды в донные отложения. Наиболее интенсивные процессы осаждения в донные отложения отмечены для никеля, свинца и цинка. Средний характер миграции наблюдается для меди и кадмия. Возрастание карбонатной жесткости воды (до 146,8 мг/л) в осенний период определяет влияние данного фактора на накопление железа, никеля и свинца в донных отложениях.

Окислительные условия в водной экосистеме Куйбышевского водохранилища преобладают в весенний период $(\mathrm{Eh}=+240$ мB), когда наблюдается повышенное содержание растворенного кислорода $(9,95$ мг/л) в воде. В летне-осеннее время за счет понижения концентрации растворенного кислорода и его интенсивного расходования на биохимические процессы в поверхностном слое донных отложений могут устанавливаться восстановительные условия.

Существующий в водном потоке спектр соединений тяжелых металлов для каждого конкретного поверхностного водоема определяется возможностью прохождения таких процессов как гидролиз и полимеризация. Также наблюдаются процессы комплексообразования ТМ с неорганическими и органическими веществами, в том числе, с хелатообразователями - гуминовыми и фульвовыми кислотами, присутствующих в природных водах, что 
обуславливает миграционную способность металлов. В ходе проведенных исследований были рассмотрены присутствующие в водохранилище доминирующие формы металлов, в которых основными лигандами могут выступать ионы ОН- , НCO3- и фульвокислотные остатки.

Нефтепродукты в водоемах могут находиться в различных миграционных формах - растворенной, эмульгированной, сорбированной на взвешенных частицах и донных отложениях, в виде пленки на поверхности воды. В результате протекания в водоеме процессов испарения, сорбции, биохимического и химического окисления нефтепродукты претерпевают различные превращения.

Содержание и миграционные процессы НП в системе вода - донные отложения определяются сезонностью, содержанием взвешенных частиц в толще слоя воды и гидрологическим режимом водохранилища. Установлено, что максимальное содержание НП в воде (до 0,068 мг/л) наблюдается в весенний период. Накопление НП в донных отложениях (до 265 мг/кг) происходит в летне-осенний период. Таким образом, осенний период характеризуется низким значением индекса загрязненности воды $($ ИЗВ $=3,45)$ и является наиболее благоприятным для протекания процессов самоочищения водных объектов от тяжелых металлов и нефтепродуктов при комплексном влиянии исследуемых факторов. 


\section{Литература:}

1. Степанова Н.Ю., Латыпова В.З., Анохина О.К., Таиров Р.Г. Сорбционная способность и факторы формирования химического состава донных отложений Куйбышевского и Нижнекамского водохранилищ // Экологическая химия. 2003. № 12(2). С. 105-116.

2. Ваганова Е.С., Давыдова О.А. Физико-химические аспекты самоочищения малых рек от тяжелых металлов (на примере Ульяновской области) // Вода: Химия и Экология. 2012. № 3. С. 21-26.

3. Давыдова О.А., Лукьянов А.А., Ваганова Е.С. Физико-химические аспекты загрязнения и очистки поверхностных вод от тяжелых металлов и нефтепродуктов природными сорбентами // Известия Самарского научного центра Российской академии наук. 2014. Т. 16. № 4(3). С. 523525.

4. Давыдова О.А., Климов Е.С., Ваганова Е.С., Ваганов А.С. Влияние физико-химических факторов на содержание тяжелых металлов в водных экосистемах: монография / под ред. Е.С. Климова. Ульяновск. УлГТУ, 2014. $167 \mathrm{c}$. 